\title{
Clay Mineralogy and Provenance of Disang Shales in NE Tethys Basin, India
}

\author{
D. Majumdar ${ }^{1}$ and B.K. Chetia ${ }^{2}$ \\ Department of Applied Geology, Dibrugarh University, Assam (NE India) \\ ${ }^{1}$ E. mail: dimaj101@yahoo.co.in, dilip57du@dibru.ac.in
}

\begin{abstract}
The Disang Group is a strategic unit of north-east Indian stratigraphy, presumably considered to contribute mega part of hydrocarbon resources to the 'Upper Assam Petroliferous Basin of NE India. The Group is dominated by kerogen rich hard, splintery black coloured shales, deposited in shallow marine environment of shrinking Tethys Basin. The present study areas of Tirap and Changlang districts of Arunachal Pradesh (NE India) is close to the basin margin at its eastern end, where the Group occurs as thick shale sequence of about $3000 \mathrm{mts}$. with intermittent flaggy sandstones.

Clay mineralogy and clay authigenesis were examined utilizing tools like Scanning Electron Microscope (SEM) and X-ray diffractograms (XRD) and bulk geochemistry. The shales are composed almost entirely of illite or mixed-layer illite-montmorillonite with minor kaolinite and chlorite. Illite appears as grain coatings and pore fillings in sandstones. Kaolinite grows in authigenic and allogenic pattern; authigenic kaolinites are book like, occupying intergranular spaces of clastic particles in sandstones; allogenic are discrete, poorly crystallized clasts with angular to irregular geometry. Pyrite is the dominant sulphide of biogenic origin in studied shales, appear either in cubic or framboid form.

The provenance compositions have been discussed based on bulk geochemical signature. The provenance of Disangs are constrained by several functions like discriminant function analysis; bivariant plots of $\mathrm{Al}_{2} \mathrm{O}_{3} / \mathrm{TiO}_{2}$, $V-N i-T h * 10$; the profile of REE and their ratios and selective trace elements etc. The present data of Eu/Eu*, $\mathrm{La} / \mathrm{Sc}, \mathrm{Th} / \mathrm{Sc}, \mathrm{La} / \mathrm{Co}, \mathrm{Th} / \mathrm{Co}$, and $\mathrm{Cr} / \mathrm{Th}$ point toward an intermediate igneous provenance. The bivariant plot of $E u / E u^{*}-T h / S c$ and chondrite normalized negative europium (Eu) anomaly shown by the Disang shales confirms importance of intermediate igneous suite contributing mega part of the Disang sediments.
\end{abstract}

Keywords: Disang Group, clay mineralogy, SEM, XRD, diagenesis, provenance.

\section{Introduction}

The Paleocene-Eocene argillaceous sedimentary sequence in the Assam-Arakan Petroliferous Basin of NE India has been represented by the Disang Group. The unit is exposed along a $3000 \mathrm{~km}$ long regional narrow mobile belt called, Indo Burma Range (IBR). Deposited under anoxic marine bottom water condition, this Group is dominated by ash grey to black coloured shales with subordinate volume of interbedded thinly laminated flaggy sandstones. It is viewed that Disang Shales (DS) contributed mega proportion of hydrocarbons to the Upper Assam Petroliferous Basin. The present study area of Tirap and Changlang districts of Arunachal Pradesh, NE India was a part of the Paleo-Tethys Basin where Disangs has its prolific development with total expression of stratigraphic sequences distinguishable as Upper and Lower Disangs, encompassing a vertical thickness of about $3000 \mathrm{~m}$ (Fig. 1). The sedimentary facies locally preserve sedimentation documents of distal shelf to tidal flat environment. Geographically, the present study terrain is important as the oil producing fields of Kharsong and Manabum are situated nearby.

The geological account of DS has been constrained by only a handful number of published literature devoted to the physical description of geology, especially from the point of coal exploration. The early geological accounts on physical appearance of DS were forwarded by Meddlicott, $(1865)^{[1]}$; Mallet, $(1876)^{[2]}$ and Pascoe, $(1911)^{[3]}$. Few notable recent workers are: Sinha and Chatterjee, $(1982)^{[4]}$; Rangarao $(1983)^{[5]}$; Acharyya et al., (1986) ${ }^{[6]}$; Uddin et al., (2007) ${ }^{[7]}$; Acharyya, (2010) ${ }^{[8]}$; Majumdar and Chetia $(2011,2015)^{[9,10]}$.

This presentation is an attempt to report clay mineralogy and provenance composition of DS in this part of the Tethys Basin. 


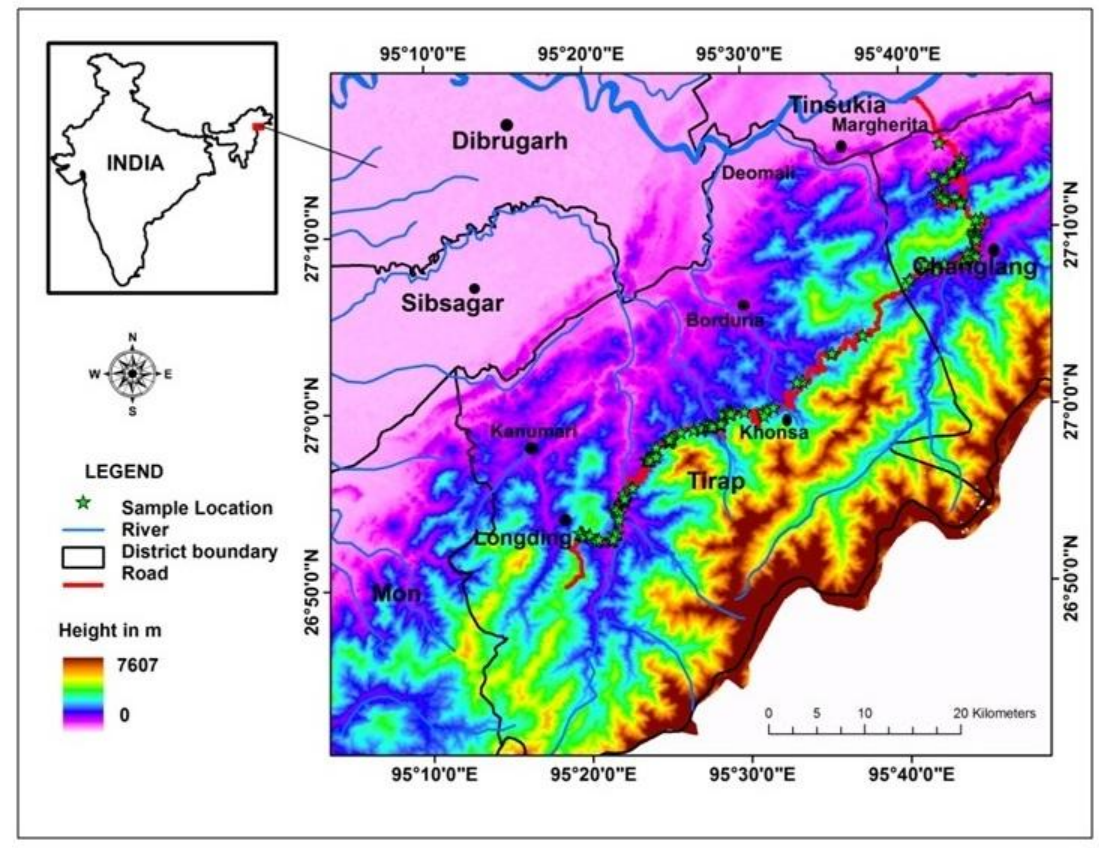

Figure: 1 location map of the study area with sample locations

\section{Geological Settings}

Exposed along the easternmost culmination of Indo Burma Range (IBR), the Disang Group has two distinct members viz., Lower and Upper Disangs. The Lower Disang is dominated by shales but the Upper Disang maintains a coarsening upward sequence with an increase in sand:shale ratio, conforming to the gradual shallowing of the basin with time. The DS are grey to black in color, splintery; sandstones are dark to light grey colored, indurate, flaggy and thinly bedded (Fig. 2 a, b). The present study area of Tirap and Changlang sectors of southwest Arunachal Pradesh (Long. $95^{\circ} 30^{\prime} \mathrm{E}$ and $95^{\circ} 42^{\prime} \mathrm{E}$; Lat. $26^{\circ} 58^{\prime} \mathrm{N}$ and $27^{0} 15^{\prime} \mathrm{N}$ ), NE India exposes Disangs with distinct facies variations. The IBR in nearby study section is annexed to the eastern end of the
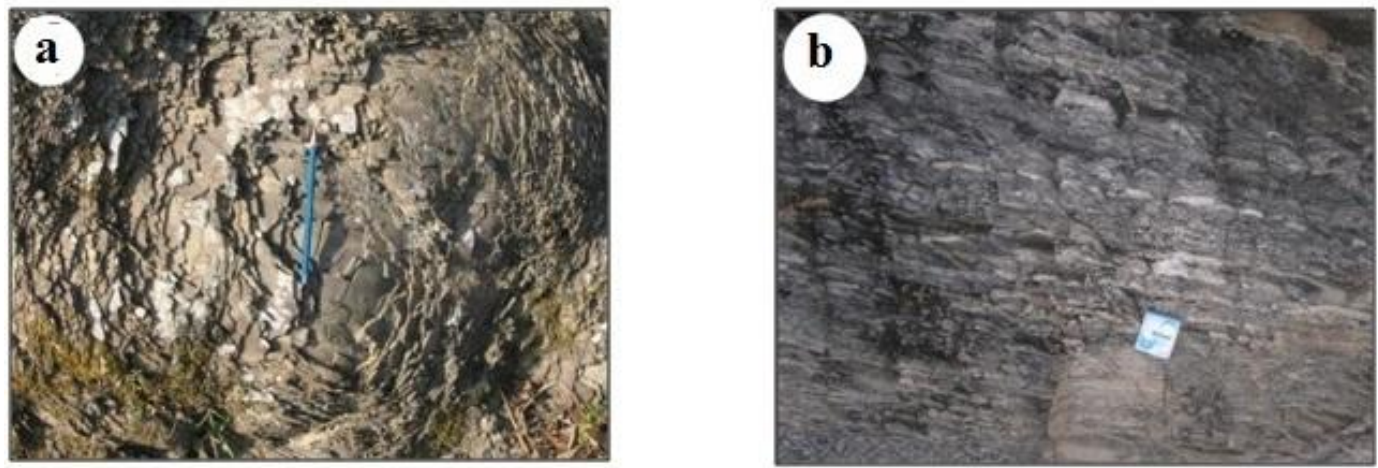

Figure: 2a. onion leaf like weathering of Disang shale (Near $4 \mathrm{~km}$ from Changlang).

b. finely laminated sand-shale sequence- a characteristic of tidal flat environment.

Himalayas, where it is edged by NW-SE trending Mishmi Thrust; bringing continental arc filled Paleogene flysch sediments in contact with the Precambrian metamorphics and crystallines. The flysch sediments exposed in the study sections show local development of turbidite sequence of deep distal shelf to tidal flat depositional settings like flute casts, load casts, slump structures, and convolute bedding.

The base of lower rhythmic steel grey coloured, fissile monotonous shale unit of the 'Disang Group' is however, not exposed in the study section. The gradual coarsening upward sequence of the Upper Disangs conformably phasing out to an upper arenaceous unit of overlying Barail Group, called 'Naogaon Formation' (Fig. 3). It is believed that block faulting holds the sedimentary load of Lower Disangs regionally in a rapidly sinking shallow fore-arc basin where there is a gradual change in depositional bathymetry toward upper part with the volumetric increase in arenaceous contents (Sinha and Chatterjee, op. cit. ${ }^{[4]}$; Bhattacharjee, $1997^{[11]}$ ). 


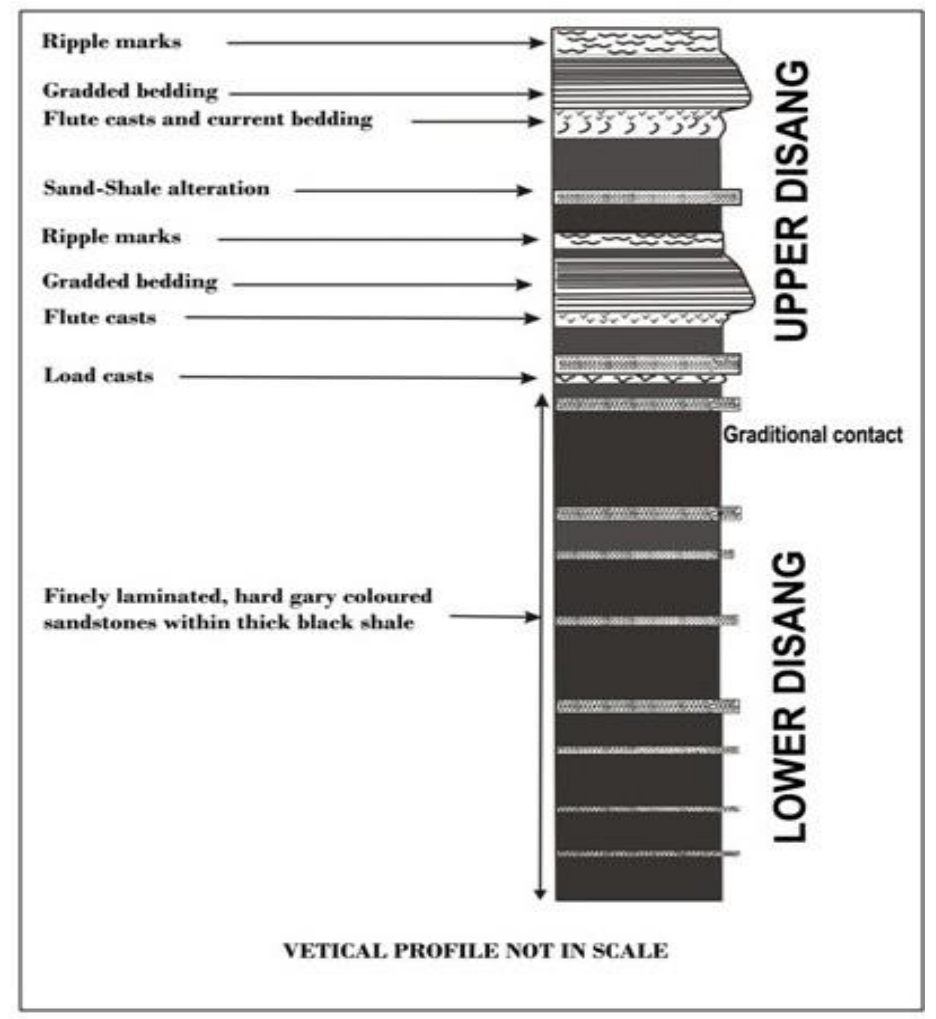

Figure: 3 vertical profile of the stratigraphy of study area.

The stratigraphy of Disang Shale is the expression of the basin evolution as a direct consequence of northward movement of the Indian plate in relation to the Eurasian and Burmese plates. The Assam-Arakan basin witnessed two major phases of basin developments between early Cretaceous to post Oligocene times. During Early Cretaceous to the end of Oligocene, there was a composite shelf-slope basinal system under a passive margin setup when the Assam shelf began to tilt toward southeast. In post Oligocene time, block faulting was reactivated, counterclockwise rotation of the Indian plate causes gradual closure of the Tethys Sea.

The regional palaeo-geographic reconstruction prior to the deposition of DS has been viewed in terms of its initial position in an intra continental portion, as a part of greater Gondwanaland. Continental rift induced separation from Gondwanaland initiated northward journey of the Upper Assam shelf facing toward the Tethys open sea ahead. All the Cretaceous and Paleogene shelf sediments were deposited during this period. With northward progression of India, the Tethys Sea gradually became thin; there was simultaneous under-thrusting of the oceanic crust below Eurasian continental crust, ultimately led to the total consumption of oceanic crust. The compressional tectonism created a regional isoclinal anticline in Tirap district, plunging toward ENE, called Nampong anticline (Acharyya ${ }^{[8]}$ ). Occasionally, there is the occurrence of Ophiomorpha and other trace fossils, plant fragments and rare local development of coaly facies. Rangarao ${ }^{[5]}$ observed evidences of shallow water marine deposition with high carbonaceous contents in certain sections of Disang sedimentation.

\section{Materials And Methods}

Twenty thin petrogarphic sections were prepared following standard procedure; conoscopic observations helped identification of framework grains. For petrographic study, Olympus BX51 reflected cum transmitted light microscope was used. Photomicrographs were obtained using image analyzer attached with the microscope.

Eight oriented shale samples were analyzed by X-ray diffraction (XRD) to oversee the clay mineralogical composition in shales. The clay size fraction (less than $2 \mu \mathrm{m}$ ) drawn from shales weighing about $25 \mathrm{~g}$ of the rock sample was soaked in distilled water after adding $5 \mathrm{ml} / 1$ of $0.1 \mathrm{~m}$. $\mathrm{Na}_{4} \mathrm{P}_{2} \mathrm{O}_{7} .10 \mathrm{H}_{2} \mathrm{O}$, and disintegrated with a shaker machine. The clay fraction $(<2 \mu \mathrm{m})$ was separated out from the sample by centrifuge method. The $<2 \mu \mathrm{m}$ suspension was smeared and dried on glass slides. For confirmation of specific mineral species only one representative oriented mount was run separately in three modes viz., i) in air dry state; ii) glycolated with ethylene glycol and iii) heated to $550^{\circ} \mathrm{C}$ for 1 hour. 
The bulk samples and the clay fractions were examined by a Philips X-ray diffractometer PW1710, with Ni filtered $\mathrm{CuK} \alpha$ radiation using $50 \mathrm{kV} / 30 \mathrm{~mA}$. The scan was made between 2 Theta $(\theta)=4$ to 40 degrees. Interpretations were made following the JCPDS Journal; Biscaye (1965) ${ }^{[12]}$ and Lindholm $(1987)^{[13]}$.

Comprehensive Scanning Electron Microscopy (SEM) was employed for determining clay mineralogy and clay authigenesis in sandstones to diagnose clay authigenesis and deposition pattern in intergranular pores and fractures; the diagenetic relationships; quartz overgrowth; effect of pressure solutions etc. Identification of clay minerals through SEM was facilitated qualitatively based on characteristic morphologies comparing with the minerals incorporated in SEM Petrology Atlas by Welton $(2003)^{[14]}$. Identification was verified by X-ray diffraction analysis whenever possible. SEM analyses were carried in Geological Lab of Oil India Ltd., Duliajan in SEM (HITACHI) TEM1000 Table Top Microscope.

To perform bulk geochemical analyses, selected samples were crushed to 230 ASTM mesh size. Major element analysis was done by X-ray fluorescence (XRF); selected trace and Rare Earth Elements (REE) were analyzed in Inductively Coupled Plasma - Mass Spectrometry (ICP-MS).

X-ray fluorescence (XRF) study was carried out in USIC, Gauhati University. Total twenty one (21) samples were analyzed for major elemental oxides in PAN analytical make, Model Axios using beads prepared from the powdered sediment samples. The bead is prepared by $4 \mathrm{~g}$ lithium Tetraborate, $1 \mathrm{~g}$ lithium carbonate, $1 \mathrm{~g}$ sample. The beads are fused in an Au-pt crucible at $1100^{\circ} \mathrm{C}$. All the analysis is done by using X-40 Software.

Rare Earth Elements (REE) and trace elements viz., Cs, Rb, Ba, Zr, U, Th, Ta, Hf and $\mathrm{Nb}$ for ten (10) samples were analyzed in ELAN DRC II, Perkin Elmer Sciex ICP-MS instrument at the National Geophysical Research Institute (NGRI), Hyderabad, India. For this analysis, 100mg of powdered samples was dissolved in acid mixture $\left(\mathrm{HF}+\mathrm{HNO}_{3}+\mathrm{HClO}_{4}\right)$ in an open vessel and heating on a hot plate at atmospheric pressure following the technique of Roberts and Ruiz (1989) ${ }^{[15]}$.

\section{Results}

\subsection{Clay mineralogy}

The Disang sandstones are hard; constituent grains are dominated by quartz, chert, rock fragments and clay matrix; cemented by siliceous or ferruginous cement (Fig. 4a). Framboidal pyrites and cuboids are common in the Disang Shales (Fig. 4b). Illite is the dominant clay mineral present in the studied sandstones with minor volume of kaolinite, chlorite and montmorrillonite or mixed layer clays. Illite occurs as grain coatings and pore fillings (Fig. 4c) but kaolinite occurs in two forms viz., authigenic book like crystals bridging the inter granular spaces of sandstone having distinct edges but the detrital grains are discrete, poorly crystallized clasts with angular or irregular crystal edges. SEM observations are being approved by the XRD (Fig. 5)
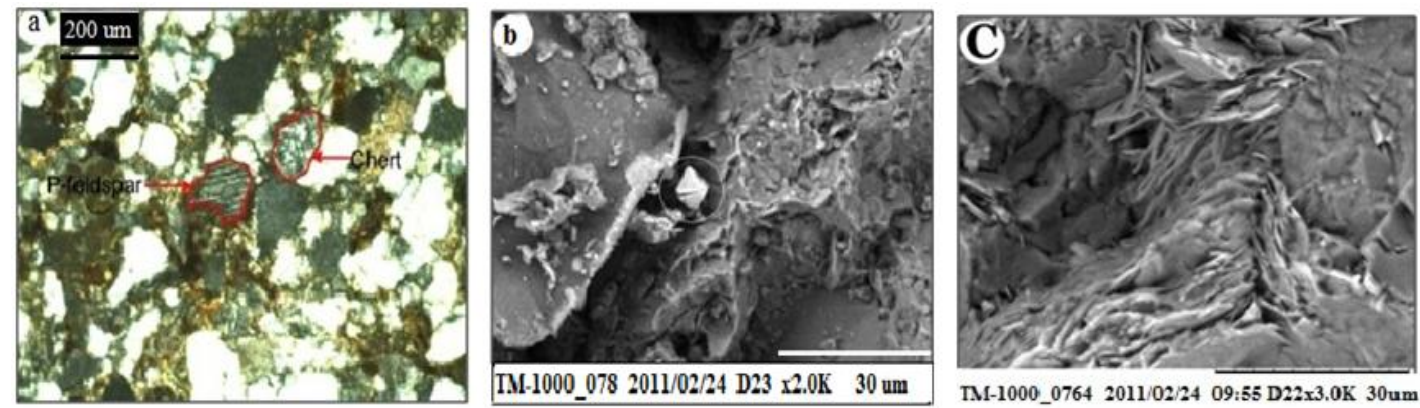

Figure: 4 a. Photomicrograph showing thin section petrography of sandstone of Lower Disang. Quartz shows

b. SEM image of euhedral pyrite in sandstone. dissolution effect.

c. SEM image showing development of flaky illlite in the sandstone pores. 


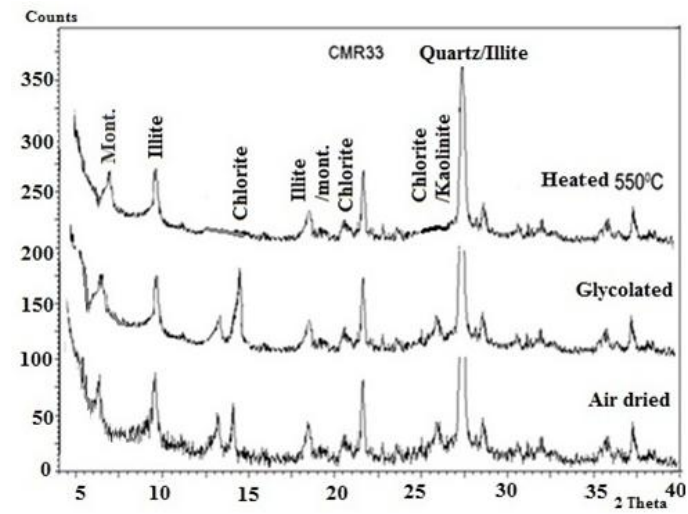

Figure: 5 representative X-ray diffractogram of oriented clay (treated sample; CMR-33)

\section{2. Geochemistry}

The geochemical analytical results of major, trace and REE elemental oxides and their correlation coefficients are presented in Table1. Data normalization has been done. Studies indicate DS contain moderate percentage of $\mathrm{SiO}_{2}(56.01-65.5 \%) ; \mathrm{Fe}_{2} \mathrm{O}_{3}(0.82-11.44 \%)$; high $\mathrm{Al}_{2} \mathrm{O}_{3}(13.65-21.05 \%) ; \mathrm{K}_{2} \mathrm{O}(2.13-4.78 \%)$ and much deficient in $\mathrm{CaO}(0.01-1.09 \%)$ and $\mathrm{Na}_{2} \mathrm{O}(1.58-2.76 \%)$. It is largely agreed that marine shales can be regarded as an admixture of three end-member oxides viz., $\mathrm{SiO}_{2}$ (detrital quartz and/or biogenic silica); $\mathrm{Al}_{2} \mathrm{O}_{3}$ (clay fraction) and $\mathrm{CaO}$ (carbonate fraction). Biogenic component of silica is mostly attributed by silica secreting organisms, like radiolaria or diatoms available in marine environment.

The results of analyzed Disang Shales (DS) in comparison to the average shales show the following: i) DS are deficient in certain Large Ion Lithofile Elements like $\mathrm{Rb}, \mathrm{Sr}, \mathrm{Cs}, \mathrm{Pb}$ and $\mathrm{Ba}$ (LILE); ii) enriched in High Field Strength Elements, e.g., Zr, Nb, Hf, Y, Th, and U (HFSE); iii) high V content in the inorganic fractions and low content of redox sensitive elements and iv) rich in immobile elements like $\mathrm{Hf}, \mathrm{Nb}, \mathrm{Ta}$ and $\mathrm{Th}$; low in $\mathrm{Th}$ and $\mathrm{Nb}$.

The total REE ( $\sum$ REE) for Disang Shale ranged from $62.74 \mathrm{ppm}$. to $202.97 \mathrm{ppm}$. with an average value of $151.59 \mathrm{ppm}$. The LREE/HREE ratio ranged from7.65-29.55 referring to the overall enrichment of LREE in studied shales. Present study show low but negative Ce (Wright et al., 1987) ${ }^{[16]}$ and small negative Eu anomaly $\left(\mathrm{Eu} / \mathrm{Eu}^{*}=0.72-0.80\right)$.

\subsection{Clay authigenesis}

\section{Discussion And Conclusions}

The authigenic development of illite is well described by the illitization process, indicates the late diagenetic alteration. Lynch, (1997) ${ }^{[17]}$ states that the authigenic illite is recognized in basins worldwide as a single volumetrically most significant reaction in the late diagenesis of siliciclastic materials. In Disang sandstones, illite bridges the primary pores and even acts as cement; such is the case commonly observed in many other types of sandstone (Macchi, 1987 $7^{[18]}$; Ehrenberg and Nadeau, 1989) ${ }^{[19]}$. In the process of illitization, detrital smectite transform through replacements (Hower et al., 1976 ${ }^{[20]}$; Pearson and Small, 1988 ${ }^{[21]}$; Furlan et al., $1996^{[22]}$ ); precipitation of illite is, however, strongly temperature dependent (Eslinger and Glasmann, 1993 ${ }^{[23]}$; Huang et al., $1993^{[24]}$, and thus, illite content increases with depth in relatively young basins. Numerous reactions have been proposed to describe the process of illitization of smectite within shales. Compared to smectite, illite is enriched in $\mathrm{Al}$ and $\mathrm{K}$ but deficient in $\mathrm{Si}$. Hence, precipitation of illite requires supply of these ions in excess of those that are supplied by smectite. Dissolution of smectite contributes dissolved silica in excess of that needed to precipitate illite. The popular reaction, involved in illitization process has been cited by many authors (Hower et al. ${ }^{[19]}$; Pearson and Small ${ }^{[21]}$; Lynch $^{[17]}$ ):

$$
\text { Smectite }+\mathrm{Al}^{3+}+\mathrm{K}^{+}=\text {illite }+\mathrm{Si}^{4+}
$$

The above reaction states that replacement of smectite by illite requires a supply of $\mathrm{Al}$ and $\mathrm{K}$ from other mineral through dissolution. Dissolution of detrital illite and K-feldspar are the most commonly suspected sources of both elements (Hower et al. ${ }^{[19]}$; Chuhan et al., 2000 ${ }^{[25]}$;).

In general, kaolinite is abundant in the early and middle stages of diagenesis, but usually absent in the last stages (Dunnoyer de Seconzac, $1970^{[26]}$; Foscolos and Powell ${ }^{[27]}$; 1980; Boles, $1981^{[28]}$ ). As temperature rises above $100^{\circ} \mathrm{C}$ due to increased burial depth, kaolinite gets dissolved or transformed in to other minerals. In other instances, if the ratio of $\left[\mathrm{K}^{+}\right] /\left[\mathrm{H}^{+}\right]$in the pore solution increases, kaolinite is illitized (Hemley, 1959) ${ }^{[29]}$. It is also argued that Kaolinite in seawater becomes unstable as the water temperature increases above $200^{\circ} \mathrm{C}$ (Dunnoyer de Seconzac) ${ }^{[26]}$. 
While discussing clay authigenesis, the diagenetic effect on clay transformation becomes important. The presence of chlorite in the Disang Shales indicates a late phyllomorphic stage of diagenesis. It has been demonstrated that in late diagenesis, certain minerals like amorphous silica, aluminum, iron and magnesium are available; chlorite can be formed through the possible reaction, mentioned by Almon and Davies, $(1979)^{[30]}$ :

$$
2 \mathrm{Al}(\mathrm{OH}) 4 \mathrm{Mg}^{2+}{ }_{(\mathrm{aq})}+\mathrm{Fe}^{2+}{ }_{(\mathrm{aq})}=\mathrm{Fe}^{2+} \mathrm{Mg}_{4} \mathrm{Al}_{2} \mathrm{Si}_{3} \mathrm{O}_{10}(\mathrm{OH})_{8(\text { solid })}+2 \mathrm{H}_{2} \mathrm{O}_{(\mathrm{I})}+8 \mathrm{H}^{+}
$$

\subsection{Provenance composition}

The attributes of major and sensitive trace elemental make up of shales are largely dependent on the intensity of weathering of the provenance. Ultrastable minerals and elements offer good provenance indications. In our present study, chemical index of alteration (CIA) and plagioclase index of alteration (PIA) have been studied based on Nesbitt and Young $(1982)^{[31]}$ : and Fedo et al., (1995) ${ }^{[32]}$ : relations respectively:

$\mathrm{CIA}=\left[\mathrm{Al}_{2} \mathrm{O}_{3} /\left(\mathrm{Al}_{2} \mathrm{O}_{3}+\mathrm{CaO} *+\mathrm{Na}_{2} \mathrm{O}+\mathrm{K}_{2} \mathrm{O}\right)\right] \times 100$

$\& \mathrm{PIA}=\left[\left(\mathrm{Al}_{2} \mathrm{O}_{3}-\mathrm{K}_{2} \mathrm{O}\right) /\left(\mathrm{Al}_{2} \mathrm{O}_{3}+\mathrm{CaO} *+\mathrm{Na}_{2} \mathrm{O}-\mathrm{K}_{2} \mathrm{O}\right)\right] \times 100$

PIA is expressed in molecular proportions; $\mathrm{CaO} *$ is the $\mathrm{CaO}$ residing in silicate mineral fraction.

An indication of intense weathering of provenance is assumed where the CIA is close to 100 . Un weathered plagioclase has a PIA value of 50. The DS of present study shows an average CIA and PIA values 75 and 85 respectively, indicating moderate to intense weathering condition of the provenance (Table 1), under this most of the plagioclases residing in the parent rocks were converted to clay minerals, hence petrography indicate poor population of feldspar minerals.

Geochemical approaches in inferring provenance composition counted on examining several important parameters. The discrimination function analysis of Roser and Korsch $(1988)^{[33]}$ has been tested for the Disang Shales. The plots largely fall in the field represented by intermediate igneous provenance (Fig. 6). Similarly, the plots of $\mathrm{Al}_{2} \mathrm{O}_{3} / \mathrm{TiO}_{2}$ (7.04 to 28.74); and iii) $\mathrm{V}-\mathrm{Ni}-\mathrm{Th} * 10$ ternary plots (Fig. 7) support intermediate igneous provenance composition of granodiorite to tonalite composition.
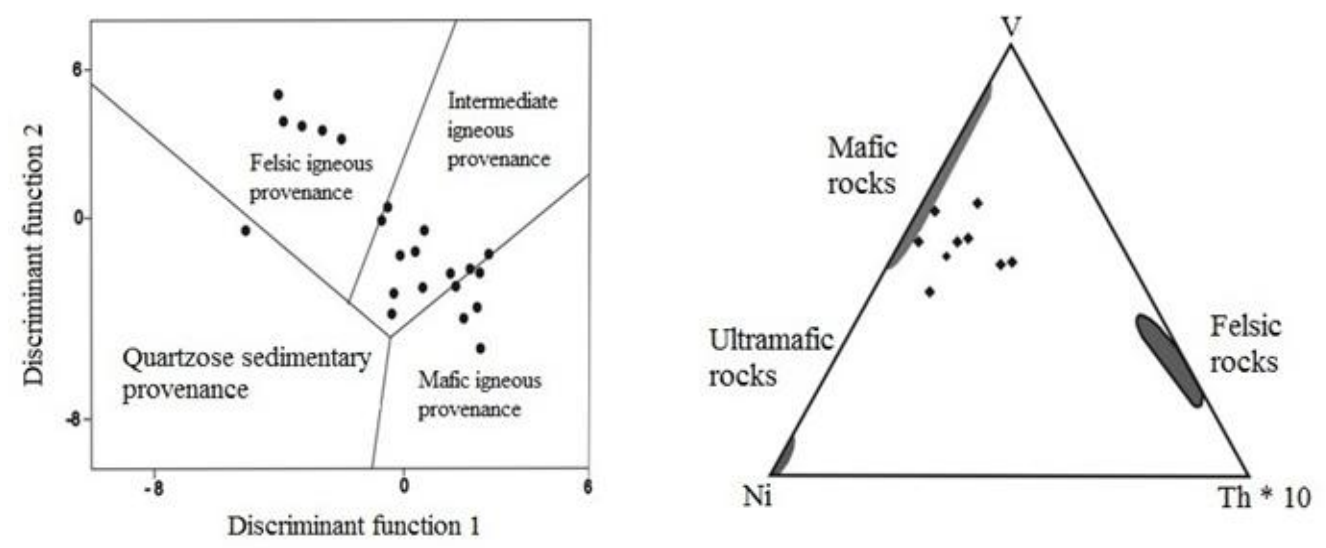

Figure: 6 discriminant function analysis of DS enumerating dominance of intermediate igneous rocks as the provenance (fields are after Roser and Korsch, 1988) ${ }^{[33]}$.

Figure: 7 V-Ni-Th*10 triangular diagram (Bracciali et al., 2007) ${ }^{[34]}$. Shaded area represents composition of felsic, mafic and ultramafic rocks. The DS plots near mafic provenance.

The HFS elements such as $\mathrm{Zr}, \mathrm{Nb}, \mathrm{Hf}, \mathrm{Y}$, Th, and $\mathrm{U}$ are poor indicator of sedimentary provenance as they preferentially partitioned into melts during progressive crystallization of magma, thereby, concentrated in felsic fraction; although, sediments derived from such rocks are controlled by the intensity of weathering prior to their derivation, hence, not considered for the present provenance study. However, the REE, Th and Sc are reliable provenance indicator, particularly due to their stability in diagenetic environment and less susceptible to heavy mineral fractionation than that for elements such as Zr, Hf, and $\mathrm{Sr}$ (Cullers et al., 1979 ${ }^{[35]}$; Bhatia and Crook, 1986 ${ }^{[36]}$; Cox et al., 1995 $5^{[37]}$; McLennan, 2001 ${ }^{[38]}$ ). The REE and Th are rich in sediments derived from felsic rocks while; other trace elements like $\mathrm{Co}$, Sc, and $\mathrm{Cr}$ are more concentrated in sediments having mafic provenance composition. The ratios $\mathrm{Eu} / \mathrm{Eu}{ }^{*},(\mathrm{La} / \mathrm{Lu})_{\mathrm{CN}}, \mathrm{La} / \mathrm{Sc}, \mathrm{Th} / \mathrm{Sc}, \mathrm{Th} / \mathrm{Co}$ and $\mathrm{Cr} / \mathrm{Th}$ and plot of $\mathrm{Eu} / \mathrm{Eu}{ }^{*}-$ $\mathrm{Th} / \mathrm{Sc}$ plot (Fig. 8), are significant indicator of mafic vs. felsic provenance and hence, considered in sedimentary studies. In the present case, the values for the DS does not show any well defined provenance for sediment derivation in terms of felsic or mafic source (Table 2), therefore, these shales were presumably derived from an intermediate igneous provenance.

In combining the parameters already considered in resolving the issue of provenance composition, the chondrite REE pattern and Europium $(\mathrm{Eu})$ anomaly and the ratio of LREE/HREE have been regarded as alternative 
indicators of provenance composition following the observation of Taylor and Mclennan, $(1985)^{[39]}$. Higher LREE/HREE ratios and negative Eu anomalies are generally found in felsic rocks, whereas the mafic rocks exhibit lower LREE/HREE ratios and no or small Eu anomalies (Cullers, 1994) ${ }^{[40]}$. The TTG (tonalite-tronjhemite-gneiss) rocks exhibit very high LREE /HREE ratios and no or small positive Eu anomalies (Cullers and Graf, 1984 $4^{[41]}$ ). The Chondrite normalized REE values for DS shows high LREE/HREE $\left(\mathrm{La} / \mathrm{Yb}_{\mathrm{CN}}=7.65-29.55\right)$ and small negative $\mathrm{Eu}$ anomaly $(\mathrm{Eu} / \mathrm{Eu} *=0.72-0.80$; Fig. 9) referring to an intermediate granodiorite - tonalite composition with minor contribution of sediments from a recycled orogen, probably from the proto Himalayas.
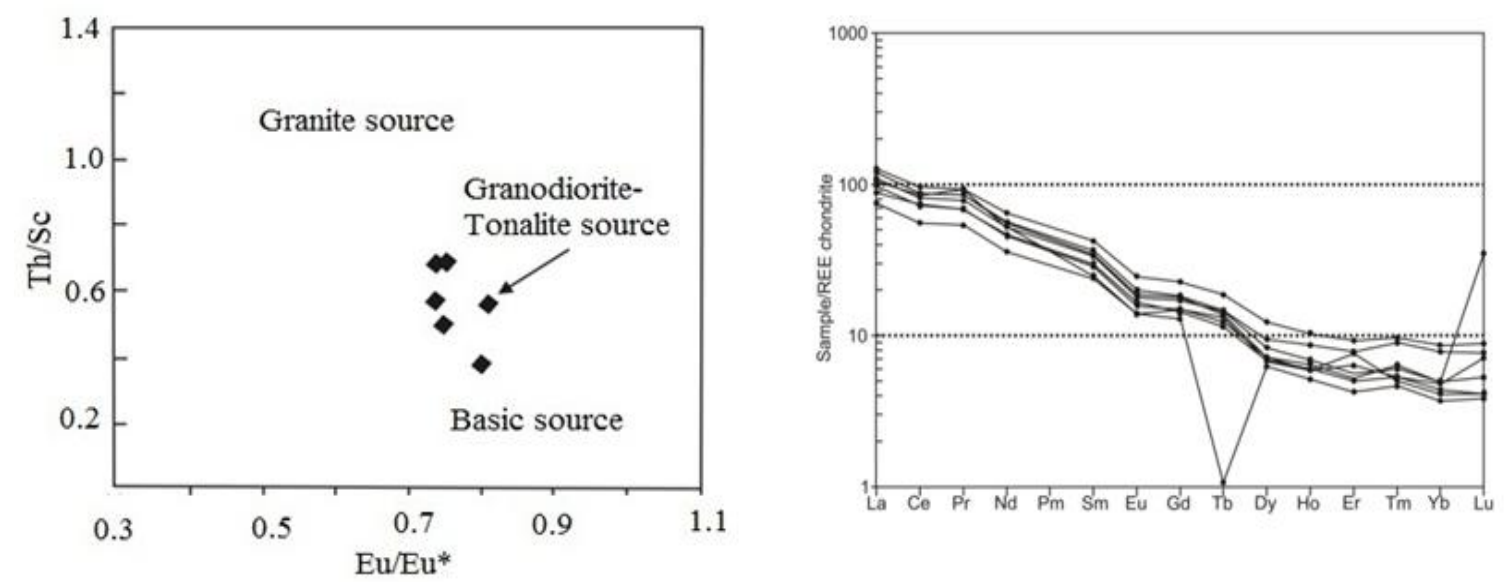

Figure: $8 \mathrm{The} \mathrm{Eu} / \mathrm{Eu}^{*}-\mathrm{Th} / \mathrm{Sc}$ plot, depicting granodiorite to tonalite provenance composition

Figure: 9 Chondrite normalized REE distribution pattern of DS having very low negative Eu anomaly, indicates non felsic -non mafic provenance composition.

Finally, the conclusions are:

1. Northward drifting of the Indian subcontinent during Paleocene-Eocene time facilitated the deposition of Disangs in Tethys Basin on distal shelf to shallow marine environment.

2. Illitisation process was dominated during post depositional diagenesis. The ultimate product was the abundant growth of authigenic illites transforming montmorrillonite (smectite) and kaolinite.

3. Provenance indicators like discriminant function analysis; composite geochemical parameters indicate dominance of intermediate igneous rocks of tonalite to granodiorite composition with minor contributions from recycled sediments.

\section{Acknowledgements}

DM is grateful to the University Grants Commission, New Delhi for funding the work under a Major Research program (Project Ref. No. F. No. 37-143/2009; SR). Thanks are due to the Head, R \& D of Oil India Ltd., Duliajan; Directors of Geochemical Division, National Geophysical Research Institute (NGRI), Hyderabad and North East Institute of Science and Technology (NEIST), Jorhat, for supporting the experimental works. Thanks are due to the district administration of Tirap and Changlang Districts for their logistic support during the field study.

\section{References}

[1]. Medlicott, H.B., 1865. The coal of Assam, results of a brief visit to the coalfields that province in 1865; with Geological note on Assam and the Hills to the south of it. Mem. Geol. Surv. Ind. Vol. 4 (pt. 3), pp. $388-442$.

[2]. Mallet, F.R., 1876. On the coal field of Naga hills, bordering the Sibsagar and Lakhimpur districts, Mem.GSI., Vol. 12 (pt. 2), pp. 1-95.

[3]. Pascoe, E.H., 1911. Coal in Namchik valley Upper Assam. Rec. G.S.I. Vol. 1 (3), pp. 214-216.

[4]. Sinha, N.K., Chatterjee, B.P. 1982. Notes on the Disang Group in parts of Nagaland and fossil fauna. Records of the Geological Survey of India, Part IV.

[5]. Rangarao, A., 1983. Geology and hydrocarbon potentials of a part of Assam-Arakan basin and its adjoining region. Petroliferous Basins of India, pp. 127-158.

[6]. Acharyya, S. K., Roy, D.K., Ghosh, S.C., 1986. Stratigraphy and emplacement history of the Naga Hills Ophiolite, Northern IndoBurmese range. In: Proceedings of 11th Micropaleontology \& Stratigraphy, Geological Mining and Metallurgical Society of Ind. Vol. 57, pp. 1-17.

[7]. Uddin, A., Kumar, P., Sharma, J. N., 2007. Early orogenic history of the eastern Himalayas: compositional studies of Paleogene sandstones from Assam, northeast India: International Geology Review, Vol. 49, pp. 798-810.

[8]. Acharyya, S. K., 2010. Tectonic evaluation of the Indo-Burma-Andaman mobile belt and the nature of its linkage with the Indian Continent. Jour. Ind. Geol. Cong. (2), pp. 41-59. 
[9]. Majumdar, D., Chetia, B.K., 2011. Role of geochemistry of the Disang Shales in the interpretation of their depositional environment. Proc. of the $17^{\text {th }}$ Conv. of Ind. Geol. Cong. And Int. Conf. NPESMD, pp. 299-311.

[10]. Majumdar, D., Chetia, B.K., 2015. Source rock evaluation of PETM generated DisangShales occurring in parts of Arunachal Pradesh, NE India. Jour. of Applied Geochemistry, Vol. 17 (1), pp. 1-9.

[11]. Bhattacharyya, C. C., 1997. Tectonism and sedimentation in the Indo Burman sedimentary basin, Jour. Geol. Sci., Vol. 2, pp. 1-8.

[12]. Biscaye, P. E., 1965. Mineralogy and sedimentation of recent deep-sea clay in the Atlantic Ocean and adjacent seas and oceans: Geol. Soc. Am. Bull., Vol. 76, pp. 803-831.

[13]. Lindholm, R.C., 1987. A Practical Approach to Sedimentology. Allen \& Unwin, London, pp. 128-153.

[14]. Welton, J.E., 2003. SEM Petrology Atlas, Pub. Amer. Aso. Petro. Geol., pp. 9-20, 35-84 and p. 187.

[15]. Roberts, S. J. and Ruiz, J., 1989. Geochemistry of exposed granulite facies terrains and lower crustal xenoliths in Mexico. Journal of Geophysical Research: Solid Earth.Vol. 94, pp. 7961-7974.

[16]. Wright, J., Schrader, H. and Holser, W.T., 1987. Paleoredox variations in ancient oceans recorded by rare earth elements in fossil apatite. Geochim.Cosmochim. Acta. Vol. 51, pp. $637-644$

[17]. Lynch, F. L., Mack, L. E., Land L. S., 1997. Burial diagenesis of illite/smectite in shales and the origins of authigenic quartz and secondary porosity in sandstones. Geochim. Cosmochim. Acta Vol. 66, pp. 439-446.

[18]. Macchi, L., 1987. A review of sandstone illite cements and aspects of their significance to hydrocarbon exploration and development. Geol. Jour., Vol. 22, pp. 333-345.

[19]. Ehrenberg, S. N., Nadeau, P. H., 1989. Formation of diagenetic illite in sandstones of the Garn Formation, Haltenbanken area, midNorweigien Continental Shelf. Clay Min., Vol. 24, pp. $233-253$.

[20]. Hower, J., Eslinger, E.V., Hower, M.E., Perry, E.A., 1976. Mechanism of burial metamorphism of argillaceous sediments: I.Mineralogical and chemical evidence: Geological Society of America, Bulletin, Vol. 87, pp. 725-737.

[21]. Pearson, M. J., Small, J. S., 1988. Illite-smectite diagenesis and paleo-temperature in northern North Sea Quaternary to Mesozoic shale sequence. Clay Min., Vol. 23, pp. 109-132.

[22]. Furlan, S., Clauer, N., Chauduri, S., Sommer, F., 1996. K transfer during burial diagenesis in the Mahakam Delta basin (Kalimantan, Indonesia).Clays Clay Min., Vol. 44, pp. 157-199.

[23]. Eslinger, E., Glasmann, J. R., 1993. Geothermometry and geochronology using clay minerals—an introduction. Clays Clay Min., Vol. 41, pp. $117-118$

[24]. Huang, W.-L., Longo T. M., Pevear, D., 1993. An experimentally derived kinetic model for smectite to illite conversion and its use as a geothermeter. Clays Clay Min., Vol. 41, pp. $162-177$.

[25]. Chuhan F. A., Bjørlykke K., Lowrey C., 2000. The role of provenance in illitization of deeply buried reservoir sandstones forms Haltenbanken and north Viking Graben, offshore Norway.Mar. Petrol. Geol., Vol. 17, pp. 673-689.

[26]. Dunoyer, de Segonzac G., (1970). The transformation of clay minerals during diagenesis and low-grade metamorphism: a review.Sedimentology, Vol. 15, pp. 281-346.

[27]. Foscolos, A.E., Powell, T.G., 1980. Mineralogical and geochemical transformation of clays during catagenesis and their relation to oil generation, in Miall, A.D., ed., Facts and Principles of World Petroleum Occurrence: Canadian Society of Petroleum Geologists, Mem. Vol. 6, pp. 153-171.

[28]. Boles, J.R., 1981. Clay diagenesis and effects on sandstone cementation (case histories from Gulf Coast Tertiary), in Longstaffe, F.J., ed., Clays and the Resource Geologist: Mineralogical Association of Canada, Short Course Handbook, Vol. 7, pp. 148-168.

[29]. Hemely, J.J., 1959. Some mineralogical equilibria in the system (K20-A1203-Si02-H2): American Journal of Science, pp. 257, 241270 .

[30]. Almon, W.R., Davies, D.K., 1979. Regional diagenetic trends in the Lower Cretaceous muddy sandstones Powder River Basin: in P.A. Scholle and P.R Schluger, eds., Aspects of Diagenesis : Society of Economic Paleontologist and Mineralogists special publication, Vol. 26, pp. 579-400.

[31]. Nesbitt, H.W., Young, G.M., 1982. Early Proterozoic climates and plate motions inferred from major element chemistry of lutites .Nature, Vol. 299, pp. 715-717.

[32]. Fedo, C. M., Nesbitt, H. W., Young, G. M., 1995. Unraveling the effects of potassium metasomatism in sedimentary rocks and paleosols, with implications for paleoweathering conditions and provenance, Geology, Vol. 23, pp. 921-924.

[33]. Roser, B. P., Korsch, R. J., 1988. Provenance signatures of sandstone-mudstone suites determined using discriminant function analysis of major-element data .Chemical Geology, Vol. 67, pp. 119-139.

[34]. Bracciali, L., Marroni, M., Pandolfi, 1., and Rocchi, S., 2007. Geochemistry and petrography of Western Tethys Cretaceous sedimentary covers (Corsica and Northern Apennines): from source areas to configuration of margins. In : Arribas, J., Critelli, S., Johnsson, M.J. (Eds). Sedimentary Provenance and Petrogenesis, Perspectives from Petrography and Geochemistry, Geological Society of American special paper, 420, 73-93.

[35]. Cullers, R.L., Chaudhuri, S., Kilbane, N., Koch, R., 1979. Rare earths in size fractions and sedimentary rocks of PennsylvanianPermian age from the mid-continent of the USA: Geochimica et Cosmochimica Acta, Vol. 43, pp. 1285-1302.

[36]. Bhatia, M.R., Crook, K.A.W., 1986. Trace element characteristics of graywackes and tectonic setting discrimination of sedimentary basins. Contributions to Mineralogy and Petrology, Vol. 92, pp. 181-193.

[37]. Cox, R., Lowe, D.R., Cullers, R.L., 1995. The influence of sediment recycling and basement composition on evolution of mudrock chemistry in the southwestern United States. Geochimica et Cosmochimica Acta, Vol. 59(14), pp. 2919-2940.

[38]. McLennan, S.M., 2001. Relationships between the trace element composition of sedimentary rocks and upper continental crust. Geochem. Geophys. Geosyst. (G3) 2 (paper\# 2000GC000109).

[39]. Taylor, SR., and McLennan S. M., 1985. The continental crust: its composition and evolution. Blackwell, Scientific Publication, Carlton, pp. 312.

[40]. Cullers, R.L., 1994. The controls on the major and trace element variation of shales, siltstones and sandstones of PennsylvanianPermian age from uplifted continental blocks in Colorado to platform sediment in Kansas, USA: Geochimica et Cosmochimica Acta, Vol. 58 (22), pp. 4955-4972.

[41]. Cullers, R.L., Graf, J., 1984. Rare earth element in igneous rocks of the continental crust: intermediate and silicic rocks, ore petrogenesis, in Henderson, P. (ed.), Rare Earth Geochemistry, Elsevier, pp. 275-316. 